\title{
What Alterations can be seen in the Soil Seed Bank after Eucalyptus Harvest?
}

\author{
Samara Welter Duarte ${ }^{1}$ (i) 0000-0003-0842-7124 \\ Daiane Luchetta Ronchi ${ }^{1}$ (i) 0000-0003-0216-3367 \\ Lauri Amândio Schorn ${ }^{1}$ (D) 0000-0003-3732-5354 \\ Tatiele Anete Bergamo Fenilli ${ }^{1}$ (D) 0000-0003-3474-5935
}

\begin{abstract}
The objective of this study was to assess the potential and the alterations of the soil seed bank as a mechanism for the regeneration of tree species in disturbed forest fragments after Eucalyptus grandis harvest. Soil samples were collected in two periods, during the winter and summer, in areas with different ages after E. grandis harvest. In each environment, 20 samples of soil were collected, with 60 samples per period (winter and summer), this samples were distributed in trays and arranged in open air for germination analysis. A total of 2,002 individuals were identified, belonging to 36 species and 17 families. The highest densities occurred during the summer, which also showed higher similarity between the environments. More species and diversity in relation to the ages of regeneration was observed during this period. Therefore, this study represents a contribution for further experiments in the field of conservation and restoration.
\end{abstract}

Keywords: succession, natural regeneration, floristic composition.

\section{INTRODUCTION AND OBJECTIVES}

The formation of fragmented landscapes and the reduction of biodiversity in forests are the main consequences of deforestation, generated mainly by agriculture and pasture introduction (Laurance et al., 2011; Sandor \& Chazdon, 2014; Santo-Silva et al., 2013). The result of this fragmented landscape, the increase in the isolation of the area, and the decrease in the average forest size might change the future patterns of plants distribution, as well as species richness and its persistence in the remaining fragments of forests (Plue \& Cousins, 2013).

Therefore, it is essential to understand the role of soil seed banks for regeneration, not only to assess the vulnerability of forests but also to support strategies for the conservation and maintenance of biodiversity (Madawala et al., 2016; Williams-Linera et al., 2016). The soil seed bank is an essential mechanism for natural regeneration and vegetation recovery, especially in the tropical forest ecosystem, thus, indicating the state of conservation and the potential for ecosystem restoration (Kinugasa \& Oda, 2014; Martins \& Engel, 2007; Martins et al., 2008).
The soil seed bank is characterized by the composition of viable seeds in the soil or associated with leaf litter, in a specific area and time (Schorn et al., 2013), and it is an effective mechanism to establish plant communities (Plue \& Cousins, 2013). Furthermore, the soil seed bank is considered to be the main resource of species recruitment as well as a dynamic system, with inputs of seed rain and dispersion (Reis et al., 2003; Schorn et al., 2013).

Most of the studies about soil seed banks have been well described and are mostly about the potential for restoration use and composition (Kinugasa \& Oda, 2014; Madawala et al., 2016; Martins \& Engel, 2007; Plue \& Cousins, 2013; Tres et al., 2007), but there have been only few studies about the alterations after harvest of some economically important species (Ikeda et al., 2008; Santos et al., 2010). We studied three areas with different abandoned ages after Eucalyptus harvest in Brusque, Santa Catarina, Brazil to enhance the knowledge about the alterations in the soil seed bank, their compositions and differences that could be found in these areas.

As a result, we hope that the composition of the soil seed bank follows the changes in the vegetal community

${ }^{1}$ Universidade Regional de Blumenau (FURB), Blumenau, SC, Brasil 
in the same area, and it seems that the observation of the floristic structure in the soil seed bank can reveal the most usual species and botanic families (Ikeda et al., 2008). Therefore, the objective of this study was to assess the potential of the soil seed bank as a mechanism for the regeneration of tree species and the alterations of the seed bank in disturbed forest fragments at different ages and in different periods (winter and summer) after Eucalyptus grandis Hill ex Maiden harvest.

\section{MATERIALS AND METHODS}

\subsection{Study site}

This study was carried out in the municipality of Brusque, Santa Catarina, Brazil (Figure 1), in a former area of agriculture and surrounded by watercourses and forests remnants. This area belongs to a company that cultivated Eucalyptus grandis for energy production. The place was left as a nature reserve to follow the law. The property is inserted in the watershed of the Itajaí River, within the subbasin of the Itajai Mirim River, in an approximate altitude of 206 meters, and geographic coordinate system $27^{\circ} 2^{\prime} 7^{\prime \prime} \mathrm{S}$ and $48^{\circ} 54^{\prime} 40^{\prime \prime} \mathrm{O}$.
According to the Köppen classification, the climate of this region is $\mathrm{Cfa}$ - humid subtropical climate with warm summers and without dry season. The annual mean temperature fluctuates between $18^{\circ} \mathrm{C}$ and $20^{\circ} \mathrm{C}$, the annual mean precipitation ranges between $1,700 \mathrm{~mm}$ and $1,900 \mathrm{~mm}$, and it is well distributed during the year with relative humidity between $84 \%$ and $86 \%$ (Alvares et al., 2014).

In the region of Brusque, the geology is formed by the metamorphic complex of Brusque, which is composed especially by the Botuverá formation, composed of Granodiorito Valsungana and Granito Guabiruba. The most usual soil in the area is Ultisol (US Soil Taxonomy) or Argissolo VermelhoAmarelo (Brazilian Soil Classification System) (Embrapa, 2006). The vegetation of the study site is inserted in a tropical rain forest phytoecological region (IBGE, 2012).

\subsection{Seed bank analysis}

The soil samples were collected in two periods, August 2013 (winter) and February 2014 (summer), in three areas near the watercourse within different regeneration ages: Environment I (AI) with five and a half years of regeneration; Environment II (AII) with seven years of regeneration and Environment III (AIII) with nine years of regeneration.
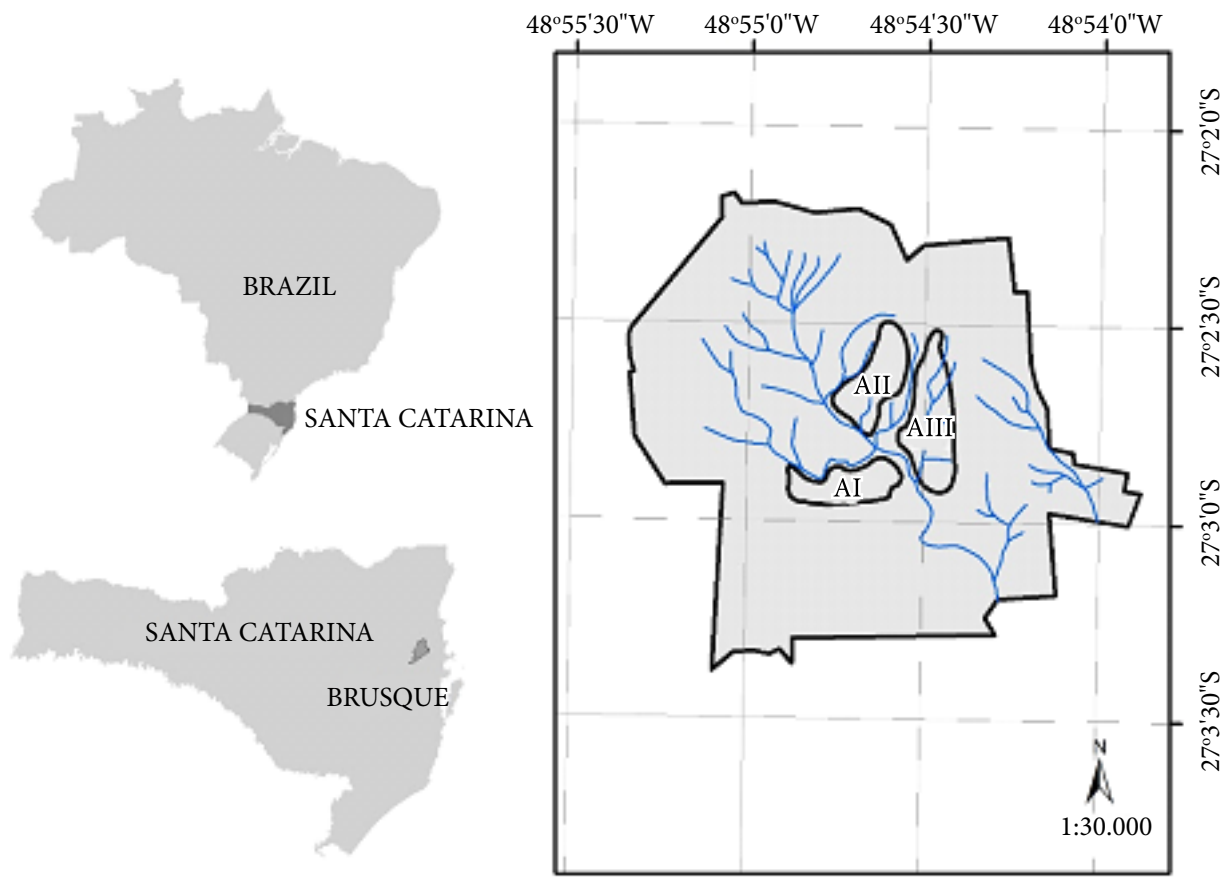

Figure 1. Location of the municipality of Brusque, Santa Catarina, Brazil, and the study site - Environment I (AI) with five and a half years of regeneration; Environment II (AII) with seven years of regeneration and Environment III (AIII) with nine years of regeneration. 
In each environment, 20 samples of soil $(0.5 \mathrm{~m} \times 0.5 \mathrm{~m})$ were collected, with 60 samples per period (winter and summer). The samples were randomly distributed. The superficial leaf litter was discarded, and the soil was collected in a depth of $10 \mathrm{~cm}$, it was used a shovel.

The soil was stored in plastic bags, tagged and transported to the tree nursery at the Universidade Regional de Blumenau (FURB). A total of 60 plastic trays $(60 \mathrm{~cm} \times 40 \mathrm{~cm} \times 10 \mathrm{~cm})$ were used per period in the experiment. Each plastic tray was filled with vermiculite layers, both above and underneath the soil layer. The plastic trays were organized in seedbeds in an open field. As control measure, we organized three plastic trays with substrate only.

Each plastic tray was drilled to avoid excess of water as well as to avoid hydric stress in the plants, and the irrigation was conducted according to climatic conditions. The assessment of germination capacity was conducted monthly for 6 months in each period. The species that had not been identified were replanted in polyethylene bags with substrate, whereas the identified species were quantified and removed from the plastic trays.

\subsection{Data analysis}

The species were classified according to their ecologic group - pioneer and non-pioneer species - and also according to their life form - arboreal, herbaceous, shrubby and pteridophyte. The individuals were identified according to the literature, compared with other plants and by specialists' opinion in vegetal taxonomy.

The mean density of emerged seedlings was compared using Wilcoxon non-parametric test to determine differences between treatments. The diversity of species in the seed bank was estimated for each area using Shannon's diversity index and Pielou's evenness index. The similarity of floristic composition was estimated among the environments using Sorensen's index. All analyses of this study were performed in the statistical program PAST (Paleontological Statistics) version 2.17c (Hammer et al., 2001).

\section{RESULTS}

\subsection{Seed bank composition}

A total of 2,002 individuals ( 8.808 ind $\mathrm{m}^{-2}$ ) were collected both in the summer and winter, within 36 species, 21 genres, and 17 botanic families. Two individuals were identified as the same botanic family, ten individuals were identified in the same genre level and two individuals were not identified. The botanic families with the highest number of species were Malvaceae (six), Asteraceae (five), and Solanaceae (four). These three botanic families represented a total of $24.7 \%$ from all the identified species.
The soil seed bank collected in the winter had 351 individuals

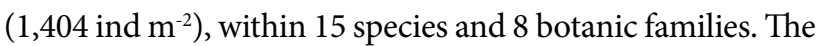
most representative families were Malvaceae and Poaceae with three species each. However, in the summer, the density of individuals was higher with 1,651 individuals $\left(6,604 \mathrm{ind}^{-2}\right)$, within 31 species and 16 botanic families. The most representative families in the summer were Asteraceae with four species, and Malvaceae e Poaceae with three species each.

Ten species that belong to five botanic families in AI were identified in the winter. The most expressive families were Rubiaceae (32.5\%), Poaceae (26.5\%), and Malvaceae (15.7\%). The most representative species were Brachiaria sp.2, Sida rhombifolia (L.), and Mitracarpus hirtus (L.) DC. Whereas in AII (winter), 11 species and six botanic families were identified. In this environment, the most representative families were Malvaceae (40.8\%), Rubiaceae (24.3\%), and Fabaceae (23.7\%). In the same environment, the species that presented the highest density were Mimosa bimucronata (DC.) Kuntze., Sida rhombifolia (L.), and Mitracarpus hirtus (L.) DC. These species represented $80 \%$ of the density in this period and environment. In AIII (winter), 13 species and 8 botanic families were identified, from which the most expressive families are Poaceae, Malvaceae (26.3\%) and Fabaceae (18.2\%), and the species that had the highest density were Brachiaria sp, Sida rhombifolia (L.), and Mimosa bimucronata (DC.).

During summer, the same process occurred. In AI, 24 species and 15 botanic families were identified. In this area the most expressive species were Sida planicaulis Cav., Brachiaria sp.2, and Conyza sp; whereas the most representative botanic families in density were Malvaceae (32.3\%), and Poaceae (26.1\%). In AII 25 species and 16 botanic families were identified, from which the most representative were Malvaceae (22.2\%), Phytolaccaceae (11.7\%), and Cyperaceae (10.7\%). In this environment, Phytolacca americana L., Cyperus ferax Rix., and Sida sp. 2 had the highest density. In AIII, 27 species and 15 botanic families were identified. The most representative families and species were Cyperaceae (18.3\%), Malvaceae (15\%), Cyperusferax Rix., Sida rhombifolia (L.), and Ipomea sp, respectively.

\subsection{Life form and ecological group}

Regarding life form and ecological group, we identified that the highest occurrence was related to species belonging to pioneers $(80.5 \%)$ and herbaceous $(55.6 \%)$. The arboreal (8.3\%) life form was the least representative in the environments, being represented by Mimosa bimucronata, Tibouchina urvilleana (DC.) Cogn. and Piper aduncum L. This fact may occur due to external influence in the areas, such as anthropic or even the regeneration stage. 
In general, the three environments presented a pattern of herbaceous species. In AIII, the herbaceous species were represented by $53.3 \%$ of species, whereas in AII, shrubby species were represented by $37 \%$ of species, and the arboreal species had similar patterns in the three environments.

\subsection{Alterations and similarity in soil seed bank}

The total number of individuals that germinated were distinct between the periods (winter and summer) of collection and between the three environments. This difference among environments decreased over time with the increase of the regeneration ages, as shown in Table 1.

In the summer, the environment with five years of regeneration presented the highest density, with 2,888 ind $\mathrm{m}^{-2}$, and the environment with nine years of regeneration had the lowest density, with 1,356 ind $\mathrm{m}^{-2}$. In the first period (winter), the environment with five years presented the lowest density, with 332 ind $\mathrm{m}^{-2}$, and the environment with seven years presented the highest density with $676 \mathrm{ind} \mathrm{m}^{-2}$.

Table 1 provides an overview of the differences between the three environments in distinct seasons. AI and AIII (winter) did not show significant differences; in this case, the populations in these two environments were similar. AII and AIII (summer) did not present significant difference, but the data of these different regeneration ages were significantly different from AI. The results obtained in the two survey winter and summer - occasions showed significant differences, especially in number of species, families, and density. These results evidence the need to contemplate different seasons in seed bank studies to obtain more accurate results.

Shannon index and Pileou's evenness index values increased from AI to AIII in the two periods (Table 1). The gradients of diversity and equability formed between the three environments show the progression of the successional process in the areas with increasing regeneration ages, where species ingress and the more homogeneous distribution of density among species becomes evident. In general, the species were well represented in terms of individuals in the assessed environments in both periods. In the first period (winter), a greater similarity between the environments in relation to the summer assessments was observed. In the second period (summer) the AI showed a small decrease in relation to the other environments, indicating the predominance of some species in the formation of the seed bank at that period of year.

The qualitative analysis of the floristic composition - which was calculated based on the Sorensen diversity index - showed that the areas characterized by different abandonment ages had a strong similarity, as shown in Table 2. Although the differences in similarity were small between environments in both periods, the greatest similarity was determined between $\mathrm{AI}$ and AII, suggesting that these environments have less differentiated environmental conditions in relation to the period after Eucalyptus harvest, such as the levels of internal luminosity and humidity, enabling higher rate of seeds and species entry, unlike AIII.

Table 1. Total number of species, families, density of individuals per square meter, Shannon diversity index, and Pielou's evenness index in soil seed bank of natural regeneration areas after Eucalyptus grandis harvest, in Brusque, SC, Brazil.

\begin{tabular}{|c|c|c|c|c|c|c|}
\hline \multirow{2}{*}{ Parameters } & \multicolumn{3}{|c|}{ Winter } & \multicolumn{3}{|c|}{ Summer } \\
\hline & AI & AII & AIII & AI & AII & AIII \\
\hline Number of species & 10 & 11 & 13 & 24 & 25 & 27 \\
\hline Botanic families & 5 & 6 & 8 & 15 & 16 & 15 \\
\hline Density (ind $\mathrm{m}^{-2}$ ) & $332 a^{*}$ & $676 \mathrm{~b}$ & $396 \mathrm{a}$ & $2,888 \mathrm{a}$ & $2,360 \mathrm{~b}$ & $1,356 \mathrm{~b}$ \\
\hline Shannon index $\left(\mathrm{H}^{\prime}\right)$ & 1.93 & 1.94 & 2.12 & 2.22 & 2.84 & 2.89 \\
\hline Pielou's index $(J)$ & 0.84 & 0.83 & 0.82 & 0.7 & 0.88 & 0.87 \\
\hline
\end{tabular}

AI: environment with five and a half years of regeneration; AII: environment with seven years of regeneration; AIII: environment with nine years of regeneration

* Values followed by the same letter do not differ from each other by the Wilcoxon non-parametric test.

Table 2. Similarity between the qualitative floristic composition of the areas on natural regeneration process after Eucalyptus grandis harvest in Brusque, Santa Catarina, Brazil.

\begin{tabular}{|c|c|c|c|c|c|c|}
\hline \multirow{2}{*}{ Parameters } & \multicolumn{3}{|c|}{ Winter (\%) } & \multicolumn{3}{|c|}{ Summer (\%) } \\
\hline & I-II & I-III & II-III & I-II & I-III & II-III \\
\hline Sorensen similarity & 76 & 61 & 75 & 86 & 86 & 85 \\
\hline
\end{tabular}


Furthermore, AI and AII showed the highest similarity (86\%) indicating that these environments present greater floristic similarity, which is confirmed during the summer, possibly indicating a greater entry of species. AI and AIII presented the lowest similarity (61\%) in the winter period, indicating that in the summer, seed dispersion was more abundant and diverse compared with the winter. The AI environment showed a younger and more open vegetation in the winter, with the occurrence of predominately pioneer species whose seeds are more persistent in the soil; on the other hand, in the AIII environment, a smaller contingent of pioneer species was observed. Due to the presence of temporary seeds, in the winter the similarity between the AI and AIII environments tend to decrease.

\section{DISCUSSION}

\subsection{Seed bank composition}

Apparently, the same families that were identified in this study were the most representative, such as the case of Franco et al. (2012) who characterized the seed bank of a section of Secondary Semi-deciduous Seasonal Forest in Minas Gerais, and in the case of Schorn et al. (2013), who conducted their studies in Santa Catarina, Brazil, and pointed out that the Asteraceae family presented the largest number of species.

In the assessment of the soil seed bank composition, between the winter and summer collections, differences were observed considering the three species with the greatest density in each environment. However, some species presented elevated density in both periods, such as Brachiaria sp. in AI, and Sida rhombifolia, in AIII.

\subsection{Life form and ecological group}

Some authors consider that the greatest presence of pioneer individuals occurs for their intense reproductive capacity. This feature may be related to the fact that their seeds - which often present more resistant integument and consequently less water loss - have a greater viability in the soil (Melo, 2004). The same occurs with herb species that can withstand adverse climatic conditions, such as tolerate high and low temperatures, humidity, and dry environments, presenting greater capacity to produce seeds (Christoffoleti \& Caetano, 1998).

Soil seed bank studies performed by other authors have indicated the predominant presence of herbaceous species which are greatly represented by pioneer species - followed by shrubs and arboreal species (Lopes et al., 2006).

The short life cycle of the herbaceous species may be related to the high proportion of occurrence of this group (Souza et al., 2006). The same phenomenon had already occurred in experiments conducted in tropical regions with high proportions of herbaceous species detected, ranging from $25 \%$ to $90 \%$ (Garwood, 1989).

\subsection{Alterations and similarity in the soil seed bank}

Relative similarity can be observed in species and families between AI, AII and AIII environments; however, the small increase in the values between AI and AIII are possibly justified by the longer regeneration period after Eucalyptus harvest. Considering the species with higher densities in the soil seed bank, the predominance of herbaceous plants in AI was observed, as well as the inclusion of the Mimosa bimucronata tree in this group.

The differences in germinated seed density per $\mathrm{m}^{2}$ between the three environments may be related to the period of year in which the samples were collected, since one of the relevant and related aspects refers to the seasonality of the seed bank (Costalonga et al., 2006), due to climatic seasonality in the study region.

In this case, the proportion of few species with great seed production can be evidenced, corroborating the studies of Araújo et al. (2001), who verified seed bank density in forests with different succession stages $(6,17$, and 30 years old) and observed low diversity of species $\left(H^{\prime}=2.23,1.90\right.$ and 1.12$)$ and equability with $0.52,0.46$ and 0.27 .

The relevance of the results of our study is mainly related to the awareness of the region richness and its floristic composition (Baider et al., 1999). These results can also indicate the region potential for the recovery of degraded areas. The species found in the soil seed bank, in the present study, evidence the regeneration potential and the dynamics of the successional process in previously occupied areas with Eucalyptus reforestation. These species are directly related to the conditions in which each environment is found, and when established, these species contribute to the entry of others ones that will constitute the forest in more advanced stages of succession (Martins et al., 2015).

This result may indicate factors related to the permanence and appearance of plant clusters, besides the influence of variables such as soil and climate (Martins et al., 2015). When the index is higher than $50 \%$, it can be inferred that a high similarity among the communities in relation to the species found are verified (Felfili \& Venturoli, 2000).

\section{CONCLUSION}

Density and species richness vary according to the period of the year in which the collection and analysis of the seed bank in the soil occurs, following the conditions in which the study was conducted. 
The richness and density of the species increases in the soil seed bank according to the period of abandonment of the areas after the Eucalyptus harvest.

The floristic similarity between the environments was high, especially during summer, possibly indicating a greater entry of species.

Considering that the study was developed at a local scale, other studies should be conducted to assess more characteristics and they should occur in different seasons of the year. Therefore, this study represents a contribution in the field of conservation and restoration.

\section{ACKNOWLEDGEMENTS}

Conselho Nacional de Desenvolvimento Científico e Tecnológico (CNPq) and Universidade Regional de Blumenau (FURB) for financial support.

\section{SUBMISSION STATUS}

Received: 19 Feb. 2018

Accepted: 13 Sept. 2018

Associate editor: Renato Cesar Gonçalves Robert

(1) 0000-0003-0598-5112

\section{CORRESPONDENCE TO}

\section{Samara Welter Duarte}

Universidade Regional de Blumenau (FURB), Rua São Paulo, 3.250, CEP 89012-900, Blumenau, SC, Brasil

e-mail: swduarte0@gmail.com

\section{FINANCIAL SUPPORT}

Ministério da Ciência, Tecnologia e Inovação, Conselho Nacional de Desenvolvimento Científico e Tecnológico (Capes), Grant No.: 413/2013.

\section{REFERENCES}

Alvares CA, Stape JL, Sentelhas PC, Moraes Gonçalves JL, Sparovek G. Köppen's climate classification map for Brazil. Meteorologische Zeitschrift 2014; 22(6): 711-728. 10.1127/ 0941-2948/2013/0507

Araújo MM, Oliveira FA, Vieira ICG, Barros PLC, Lima CAT. Densidade e composição florística do banco de sementes do solo de florestas sucessionais na região do Baixo Rio Guamá, Amazônia Oriental. Scientia Forestalis 2011; 59: 115-130.

Baider C, Tabarelli M, Mantovani W. O banco de sementes de um trecho de Floresta Atlântica Montana. Revista Brasileira de Biologia 1999; 59(2): 319-328.

Christoffoleti PJ, Caetano RSX. Soil seed banks. Scientia Agrícola 1998; 55(esp.): 74-78. 10.1590/S0103-90161998000500013

Costalonga SR, Reis GG, Reis MGF, Silva AF, Borges EEL, Guimarães FP. Florística do banco de sementes do solo em áreas contíguas de pastagem degradada, plantio de eucalipto e floresta em Paula Cândido, MG. Floresta 2006; 36(2): 239-250. 10.5380/rf.v36i2.6455

Empresa Brasileira de Pesquisa Agropecuária - Embrapa. Centro Nacional de Pesquisa do Solo. Sistema brasileiro de classificação de solos. Rio de Janeiro: Embrapa; 2006. 412 p.

Felfili JM, Venturoli F. Tópicos em análise de vegetação. Comunicações Técnicas Florestais 2000; 2(2): 1-25.

Franco BKS, Martins SV, Faria PCL, Ribeiro GA. Densidade e composição florística do banco de sementes de um trecho de floresta estacional semidecidual no campus da Universidade Federal de Viçosa, Viçosa, MG. Revista Árvore 2012; 36(3): 423-432. 10.1590/ S0100-67622012000300004

Garwood NC. Tropical soil seed banks: a review. In: Leck MA, Parker VT, Simpson RA, editors. Ecology of soil seed banks. San Diego: Academic Press, 1989. p. 149-209.

Hammer Ø, Harper DAT, Ryan PD. PAST: Paleontological Statistics software package for education and data analysis. Paleontologia Eletronica 2001; 4(1): 1-9.

Instituto Brasileiro de Geografia e Estatística - IBGE. Manual técnico da vegetação brasileira. 2nd ed. Rio de Janeiro: IBGE; 2012.

Ikeda FS, Mitja D, Vilela L, Silva JCS. Banco de sementes em cerrado sensu stricto sob queimada e sistemas de cultivo. Pesquisa Agropecuária Brasileira 2008; 43(6): 667-673. 10.1590/S0100-204X2008000600001

Kinugasa T, Oda S. Effects of vehicle track formation on soil seed banks in grasslands with different vegetation in the Mongolian steppe. Ecological Engineering 2014; 67: 112-118. 10.1016/j.ecoleng.2014.03.078

Laurance WF, Camargo JL, Luizão RC, Laurance SG, Pimm SL, Bruna EM et al. The fate of Amazonian forest fragments: a 32-year investigation. Biological Conservation 2011; 144(1): 56-67. 10.1016/j. biocon.2010.09.021

Lopes KP, Souza VC, Andrade LA, Dornelas GV, Bruno RL. A. Estudo do banco de sementes em povoamentos florestais puros e em uma capoeira de Floresta Ombrófila Aberta, no município de Areia, PB, Brasil. Acta Botânica Brasilica 2006; 20(1): 105-113. 10.1590/S0102-33062006000100010

Madawala HM, Ekanayake SK, Perera GA. Diversity. Composition and richness of soil seed banks in different forest communities at Dotalugala Man and Biosphere Reserve, Sri Lanka. Ceylon Journal of Science 2016; 45(1): 43-55. 10.4038/cjs.v45i1.7363

Martins AM, Engel VL. Soil seed banks in tropical forest fragments with different disturbance histories in southeastern Brazil. Ecological Engineering 2007; 31(3): 165-174. 10.1016/j.ecoleng.2007.05.008

Martins SV, Almeida DP, Fernandes LV, Ribeiro TM. Banco de sementes como indicador de restauração de uma área degradada por mineração de caulim em Brás Pires, MG. Revista Árvore 2008; 36(6): 1081-1088. 10.1590/S0100-67622008000600013

Martins SV, Borges EEL, Silva KA. O banco de sementes do solo e sua utilização como bioindicador de restauração ecológica. In: Martins SV, editor. Restauração ecológica de ecossistemas degradados. Viçosa: UFV; 2015. p. 293-315.

Melo FPL. Recrutamento e estabelecimento de plântulas. In: Ferreira AG, Borghetti F. Germinação: do básico ao aplicado. Porto Alegre: Artmed; 2004. p. 237-250. 
Plue J, Cousins SAO. Temporal dispersal in fragmented landscapes. Biological Conservation 2013; 160: 250-262. 10.1016/ j.biocon.2013.02.010

Reis A, Bechara FC, Espindola MZ, Vieira NK, Souza LL. Restauração de áreas degradadas: a nucleação como base para incrementar os processos sucessionais. Natureza e Conservação 2003; 1(1): 28-36.

Sandor ME, Chazdon RL. Remnant trees affect species composition but not structure of tropical second-growth forest. PLoS ONE 2014; 9(1): 1-7. 10.1371/journal.pone.0083284

Santos DM, Silva KA, Santos JMFF, Lopes CGR, Pimentel RM, Araújo EL. Variação espaço-temporal do banco de sementes em uma área de floresta tropical seca (Caatinga) - Pernambuco. Revista de Geografia 2010; 27(1): 234-253.

Santo-Silva EE, Almeida WR, Melo FP, Zickel CS, Tabarelli M. The nature of seedling assemblages in a fragmented tropical landscape: implications for forest regeneration. Biotropica 2013; 45(3): 386-394. 10.1111/btp.12013

Schorn LA, Fenilli TAB, Krieger A, Pellens CG, Budag JJ, Nadolny MC. Composição do banco de sementes no solo em áreas de preservação permanente sob diferentes tipos de cobertura. Floresta 2013; 43(1): 49-58. 10.5380/rf.v43i1.21493

Souza PA, Venturin N, Griffith JJ, Martins SV. Avaliação do banco de sementes contido na serapilheira de um fragmento florestal visando a recuperação de áreas degradadas. Cerne 2006; 12(1): 56-67.

Tres DR, Sant'Anna CS, Basso S, Langa R, Ribas U Jr, Reis A. Banco e chuva de sementes como indicadores para a restauração ecológica de matas ciliares. Revista Brasileira de Biociências 2007; 5(1): 309-311.

Williams-Linera G, Bonilla-Moheno M, López-Barrera F. Tropical cloud forest recovery: the role of seed banks in pastures dominated by an exotic grass. New Forest 2016; 47(3): 481-496. 10.1007/s11056-016-9526-8 